\title{
Foundations and the Advancement of Postsecondary Education
}

\author{
Libby V. Morris ${ }^{1}$ \\ Published online: 18 February 2017 \\ (C) Springer Science+Business Media New York 2017
}

The diversity in students and the structures and missions of colleges and universities across the United States is staggering. Colleges range from open access to very highly selective in admissions of undergraduate students. Public and private not-for-profit research institutions stand alongside liberal arts colleges, faith-based institutions, historically black colleges and universities, single-sex institutions, 2-year and online institutions, and for-profit providers. More than 20 million students (17 million undergraduates) enroll in the $4500+$ degree-granting institutions. The public sector claims approximately three-quarters of all students, reflecting the high expectations and responsibilities placed on those institutions. Notably, almost $40 \%$ of all undergraduates attend a public two-year institution with open (or near open door) admission policies. Collectively, these institutions strive to serve the needs of a diverse student population, fulfill their respective missions, and respond to a rising list of societal expectations about the delivery and outcomes of education.

Much about students has changed over the last 30 years. Less than $50 \%$ are now traditional college age (18-22). One in 5 is over 30 years of age, and almost 1 in 10 is over 40. Slightly more than one-third attend part-time, and approximately two-thirds of students work either part-time or full-time. Additionally, educational technologies have emerged that supplement traditional courses and also allow study anywhere, anytime. Embracing the new technologies, both new providers and traditional colleges have entered the online market. Thirteen percent of students study online only, and $14 \%$ are enrolled in hybrid courses. See the Gates Foundation, http://postsecondary.gatesfoundation.org/demographics, for facts on students and postsecondary institutions.

With such variability in institutional characteristics, curricular options, and student maturity, one might expect higher levels of student achievement in college persistence and retention. Unfortunately, college outcomes, as measured by graduation rates, have fallen short of the mark. Across all colleges approximately $40 \%$ do not graduate in 6 years after initial enrollment, and open door and non-selective institutions show even lower rates of completion.

Libby V. Morris

lvmorris@uga.edu 
While student access to college has improved dramatically, public attention has turned to academic success: student retention, progression, graduation, and documented learning outcomes. No doubt the decline in state financial support, the increase in tuition rates, and the explosion of student debt has helped drive this interest. Thus, state legislatures, agencies, and foundations have intensified their focus on college costs, programs and delivery systems, and college outcomes.

Thinking about these issues, and the drivers for change, I recently took a quick tour of the website of two large foundations, the Bill and Melinda Gates Foundation and the Lumina Foundation. Each has developed projects and networks, coupled with substantive grants, to improve postsecondary education. These two foundations, like others, have clear goals for higher education, a commitment to excellence and success, and the resources to convene people and institutional networks for change.

The Bill and Melinda Gates Foundation recently released a document titled "Postsecondary Success Advocacy Priorities" (http://postsecondary.gatesfoundation.org/wp-content/uploads/ 2016/09/PostsecondarySuccessAdvocacyPriorities2016.pdf). The foundation acknowledges that millions of students have achieved success based on their college attendance, but they conclude that "the bridge has become too narrow and too hard to navigate, with a toll that is too high," especially for students of color, low-income, and first generation. The foundation's goals are to transform higher education models through partnerships so that more students can graduate with affordable, high-quality degrees or certificates. I encourage you to visit the website to learn more about the three foci: innovative solutions (i.e., digital learning, pathways for student success, and remedial education); incentives (i.e., improved data, finance/financial aid, and policy advocacy; and networks/institutional partnerships that include HBCUs, completion by design, and partner and learning networks. See the website, http://postsecondary. gatesfoundation.org/, to read about institutional experiences and successes. The site also provides information about current collaborations and initiatives jointly sponsored or funded by other foundations (e.g., Carnegie Foundation's Math Pathways: Quantway and Statway, see https://www.carnegiefoundation.org/in-action/carnegie-math-pathways/).

The range of initiatives and networks is too extensive to list here; but I will mention the C-BEN, Competency Based Education Network, which is made possible by the Bill and Melinda Gates Foundation and the Lumina Foundation. C-BEN is a national consortium focused on new models for delivering content and/or courses with highly structured learning outcomes and embedded assessment. Competency-based education garnered quite a bit of attention in the late 1970s and 80 s, but did not sustain broad-based adoption. The Western Governor's University was an early adopter of competency based education and continues to thrive. The network partnership includes four public systems (82 campuses) and 30 colleges and universities. See http://www.cbenetwork. org/ for more information. Perhaps this is an idea for your program or institution.

The Lumina Foundation, an independent, private foundation based in Indianapolis, is another major player in the postsecondary arena, https:/www.luminafoundation.org/ourwork. Its primary thrust is captured by the term "Goal 2025," whereby $60 \%$ of Americans will have obtained college degrees, certificates, or other credentials by that year. The Foundation has eight strategic goals, including mobilizing employers and communities, mobilizing higher education, advancing state and federal policy, student financial support, creating new higher education models, and creating new systems of credentials. The Lumina Foundation's 2017-20 strategic plan shows their priorities and strategic approaches to reach 40 million adults with degrees/certificates/credential by 2025. They note that state policy is critical to achieving this ambitious goal, as is their continued investment in innovation 
through grants and contracts. You might want to learn what your institution and state are doing in alignment with the Lumina Foundation.

These and other foundations have deep and ongoing commitments, not just philosophical but resource-based, to student success and the improvement of higher education overall. Given the complexities of what faculty and administrators must do every day, it would be easy to be somewhat cynical about some of the imperatives and proposed interventions; however, the foundations are committed to making a difference, have admirable goals for student success, and have broad influence across the states and nation. These websites are useful resources to learn what is on the national agenda, who the players are, and the strategies for change. Enjoy exploring! 